\title{
Standard Deviational Ellipse (SDE) models for malaria surveillance, case study: Sukabumi district-Indonesia, in 2012
}

\author{
Tris Eryando ${ }^{1}$, Dewi Susanna ${ }^{2 *}$, Dian Pratiwi ${ }^{3}$, Fajar Nugraha ${ }^{4}$ \\ From Challenges in malaria research \\ Basel, Switzerland. 10-12 October 2012
}

\section{Background}

Sukabumi District has been a malaria endemic area for 8 years. In 2004 an outbreak of malaria occurred, and more than 250 positive malaria cases are reported every year. Malaria surveillance data is still in the form of tabular data [1], therefore it is necessary to find models to support the malaria surveillance, based on spatial mapping and analysis with the use of Standard Deviational Ellipse (SDE) models. Malaria distribution maps are a strategy to target resource distribution and to focus the control program [2].

\section{Materials and methods}

The research used a cross-sectional study. Data collection through Global Positioning System (GPS) plotting, surveys and interviews based on positive malaria cases 2011-2012 derived from public health centers. Analysis of data using overlay analysis with physical environment variables, spatial statistical analysis and SDE.

\section{Results}

The highest malaria incidence occurred at ambient temperature 22-25 degrees Celsius (70\%), with an altitude of $500-1000 \mathrm{~m}(71 \%)$ in the south hills and mountainous areas; rainfall is $3453-3846 \mathrm{~mm}(50 \%)$ in the northern areas, the distance from breeding place less than $500 \mathrm{~m}$ $(84 \%)$, and interaction the physical environment with vector enabling an outbreak risk. Mean center of gravity was the center of the distribution of cases was Longitude: 106.602721 and Latitude: -7.118190. The locations of respondents were quite close together; this could mean that malaria was spread evenly due to import cases. The rotation angle of SDE was 58.524624 degrees clockwise

${ }^{2}$ Department of Environmental Health, Universitas Indonesia, Kampus UI Depok, 16424, Indonesia

Full list of author information is available at the end of the article and the area of ellipse was $146,109,759$ square meters. Standard deviational ellipse as an overview of the standard deviation of the distribution showed that the length of the $\mathrm{X}$ axis was $15,936.83 \mathrm{~m}$ and the $\mathrm{Y}$ axis was $11,673.13 \mathrm{~m}$, the ratio between the $\mathrm{X}$ and the $\mathrm{Y}$ axis wass equal to 1.3653 (Table 1). Direction of the axis of standard deviation ellipses appeared that the skewed distribution towards the northwest-southeast. Rainfall and temperature anomalies were two of the major environmental factors triggering epidemics in warm semi-arid and high altitude areas [3-5]. Physical environment of Sukabumi District supported the development and metabolism of vectors. The map provided an initial description of the geographic variation of malaria, and might assist in formulating various methods of intervention [6].

\section{Conclusion}

Standard Deviational Ellipse (SDE) models can be used to gain a better understanding of the geographical aspects of the phenomenon and identify the cause of an event, based on specific geographic patterns.

\section{Table 1 Mean Center and SDE}

\begin{tabular}{llcc}
\hline Variable & Sub Variable & $\mathbf{X}$ & $\mathbf{Y}$ \\
\hline Mean Center & Minimum & 106.487241 & -7.232089 \\
& Maximum & 106.7401 & -7.018312 \\
& Mean & 106.602721 & -7.11819 \\
& Standard Deviation & 0.041497 & 0.047272 \\
& Geometric Mean & 106.602713 & -7.118034 \\
& Harmonic Mean & 106.602705 & -7.117879 \\
SDE & SD along new axis & $7968.41 \mathrm{~m}$ & $5836.57 \mathrm{~m}$ \\
& axis length & $15936.83 \mathrm{~m}$ & $11673.13 \mathrm{~m}$ \\
\hline
\end{tabular}




\section{Author details}

'Department of Biostatistics and Population Studies, Universitas Indonesia, Kampus UI Depok, 16424, Indonesia. ${ }^{2}$ Department of Environmental Health, Universitas Indonesia, Kampus UI Depok, 16424, Indonesia. ${ }^{3}$ Center For Biostatistics and Health Informatics Studies, Universitas Indonesia, Kampus UI Depok, 16424, Indonesia. ${ }^{4}$ Center For Biostatistics and Health Informatics Studies, Faculty of Public Health, Universitas Indonesia, Kampus UI Depok, 16424, Indonesia.

Published: 15 October 2012

\section{References}

1. District Health Office: Reports of malaria cases in 2009-2011. Sukabumi DHO 2011.

2. Grover-Kopec E, Kawano M, Klaver RW, Blumenthal B, Ceccato P, Connor SJ: An online operational rainfall-monitoring resource for epidemic malaria early warning systems in Africa. Malaria Journal 2005, 4:6.

3. Omumbo A, Lyon B, Waweru SM, Connor SJ, Thomson MC: Raised temperatures over the Kericho tea estates: revisiting the climate in the East African highlands malaria debate. Malaria Journal 2011, 10:12.

4. Pietro Ceccato, Christelle Vancutsem, Robert Klaver, James Rowland, Stephen J Connor: A vectorial capacity product to monitor changing malaria transmission potential in epidemic regions of Africa. Journal of Tropical Medicine 2012, Article ID 595948, doi:10.1155/2012/595948.

5. Ubydul Haque, Ricardo JSMagalhães, Heidi LReid, Archie CAClements, Syed MAhmed, Akramul Islam, Taro Yamamoto, Rashidul Haque, Gregory EGlass: Spatial prediction of malaria prevalence in an endemic area of Bangladesh. Malaria Journal 2010, 9:120.

6. Lawrence NKazembe, Immo Kleinschmidt, Timothy HHoltz, Brian LSharp: Spatial analysis and mapping of malaria risk in Malawi using pointreferenced prevalence of infection data. International Journal of Health Geographics 2006, 5:41.

doi:10.1186/1475-2875-11-S1-P130

Cite this article as: Eryando et al: Standard Deviational Ellipse (SDE) models for malaria surveillance, case study: Sukabumi district-Indonesia, in 2012. Malaria Journal 2012 11(Suppl 1):P130.

\section{Submit your next manuscript to BioMed Central and take full advantage of:}

- Convenient online submission

- Thorough peer review

- No space constraints or color figure charges

- Immediate publication on acceptance

- Inclusion in PubMed, CAS, Scopus and Google Scholar

- Research which is freely available for redistribution

Submit your manuscript at www.biomedcentral com/submit 